\title{
A Case Study of Safa Baitul Maal- An Islamic Micro Finance Institution in Hyderabad India
}

\author{
Atif Aziz ${ }^{1} \&$ B. D. Pandey ${ }^{1}$ \\ ${ }^{1}$ Department of Management, Sadhu Vaswani College, Barkatullah University, Bhopal, India \\ Correspondence: Atif Aziz, Research Scholar, Department of Management, Sadhu Vaswani College, Barkatullah \\ University, Bhopal, India.
}

Received: November 2, 2020

Accepted: December 2, 2020

Online Published: December 10, 2020

doi:10.5430/jms.v11n4p41

URL: https://doi.org/10.5430/jms.v11n4p41

\begin{abstract}
Islamic Microfinance refers to interest free microfinance in which no interest is charged from the poorest members of the society who are (areas in which poor people are living) marked negative by commercial banks i.e. the people are not given any loans. The main aim of any Islamic microfinance institution is to help the financially backward people to set up their small businesses without adding any further financial burden on them. The other objective of Islamic Microfinance is poverty alleviation and brings the poorest of the poor in the main stream. Unlike commercial banks and conventional microfinance, the objective of Islamic Microfinance is not to make profit but to earn reward from Allah (the Creator of Universe) both in this world and Hereafter. Islamic Microfinance or Interest free microfinance is most important tool to protect poor and poorer from the clutches of Sahukars (money vendors) who give meagre amount of Rs 800-1000 to small vendors in the morning and ask for principal and interest in the evening. In this paper, the authors have taken up the study of Safa Baitul Maal (SBM) interest free microfinance based in Hyderabad India. The selected institution has also been evaluated on various aspects such as its modus operandi, current status, outreach. The institution is fairly new which started its microfinance activities in 2014 in Kishan bagh Hyderabad Telangana India. The findings are very impressive, the shariah compliance is strictly followed. The loan amount distribution which was Rs 0.1 million in 2014 has now increased to 1 million in 2019. Initially only 20 persons were given interest free loan now this number is increased to 1500 persons in 2019 and 1800 in 2020.
\end{abstract}

Keywords: interest free microfinance, Safa Baitul Maal, Islamic micro finance, India, Islamic Shariah

\section{Introduction}

Islamic microfinance works on profit and loss sharing and Qarz-e-Hasana (interest free loan). The use of interest for money creation is prohibited in Quran. Islamic Economics defines certain rules that regulate company structure, effectively preventing abuse and corruption. Islamic economics is based on social justice. For instance, Islam forbids monopolies by banning the hoarding of wealth and eliminates copyright or potency laws that would open the avenue for potential monopolies to develop in modern era. Also, Islam protects the ownership of businesses and companies by restricting ownership of companies only to those who contribute both capital and effort to the company or business, thus effectively putting the seal on such concepts as corporate takeover from becoming a reality.

\subsection{The Main Objectives of the Present Research Are}

1. Study the modus operandi of Safa Baitul Maal Microfinance.

2. Evaluation of Safa Baitul Maal Microfinance in terms of outreach, operational efficiency.

3. Identifying operational and Sharī'ah issues facing Safa Baitul Maal and providing possible ways to rectify them.

As the ultimate goal of Islamic microfinance is the social benefits maximization as opposed to profit maximization, through the creation of healthier financial institutions that can provide effective financial services to all irrespective of religion and all ethnic groups are covered at grass root level.

\section{Literature Review}

According to (Ahsanath., M.K, 2013, p2.) Interest-free economic system is an economic system highlighted by Islam. Interest makes the money a commodity and an end in itself. When money becomes the end of economic activities, 
production, distribution and values get distorted. Market starts serving only haves thus poor becomes poorer, and the gap between haves and have not increases. Thousands of interest free micro financing institutions are functioning throughout the world. Their major objective is to eradicate human suffering by eliminating interest from the society and promotion of ultimate welfare of individuals and society in both this world and hereafter world Most of them are functioned by various Islamic organizations.

According to (Aslam M., N. 2014, p. 143), micro-finance is a big terminology which is used to provide the financial services to the poor people of third world, in the form of individual loan, group loans, micro leasing, micro loans, micro insurance, and the fund transfer to develop their business and assist them for exceptional emergencies.

(Obaidullah 2008, p. 13) stated that poverty levels have also been associated with high inequality alongside low productivity. In Indonesia alone with the world's largest Muslim population, over half of the national population, about 129 million people, are poor or vulnerable to poverty with incomes less than merely US\$2 a day. Bangladesh and Pakistan account for 122 million each followed by India at approximately 100 million Muslims below poverty line.

As stated in (Ethica Institute of Islamic Finance 2017, p.105), obviously, this is totally a wrong assumption. According to Shari 'ah, interest free loans are meant for cooperative and charitable activities, and not normally for commercial transactions, except in a very limited range. So far as commercial financing is concerned, the Islamic Shari 'ah has a different setup for that purpose. The principle is that the person extending money to another person must decide whether he wishes to help the opposite party or he wants to share his profits. If he wants to help the borrower, he must rescind from any claim to any additional amount. His principal will be secured and guaranteed, but no return over and above the principal amount is legitimate. But if he is advancing money to share the profits earned by the other party, he can claim a stipulated proportion of profit actually earned by him, and must share his loss also, if he suffers a loss.

As stated in (Ethica Institute of Islamic Finance 2017, p. 5), all that we had borrowed up to 1985 or 1986 was around $\$ 5$ billion and we have paid about $\$ 16$ billion yet we are still being told that we owe about $\$ 28$ billion. That $\$ 28$ billion came about because of the injustice in the foreign creditors' interest rates. If you ask me what is the worst thing in the world, I will say it is compound interest." President Obasanjo of Nigeria, G8 summit, Okinawa, 2000

According to Aziz, A., PANDEY, B. D., Shafique, S. 2017 p.306), the main aim of the institution is to protect poor people from the clutches of "Sahukars" (money lenders) asking high rate of interests on borrowed money as high as $60 \%$ of the principle amount .In India, the population of Muslims is about 180 million and the majority of them live below poverty line. The regions where poor Muslims are in majority are marked as negative for providing loans by the banks. Study on interest-free (Islamic) micro-finance for implementation in a country like India can be very helpful in eradicating poverty and developing micro-enterprises together with sustainable development of poor and country as a whole.

According to (Aziz, A., PANDEY, B., D. 2017 , p.1), another report tells us that SKS Micro-finance is charging approximately 24 per cent rate of interest in Orissa, Karnataka and Andhra Pradesh; in southern India, Equitas Micro-finance is seeking 21-28 per cent interest rate and Basix Microfinance is providing small loans at 18-24 per cent interest rate. There are numerous other players, and they all rake in money. Sewa in Gujarat and the Grameen Bank in Bangladesh too thrive on similarly high rate of interest. It is shocking that a poorest of the poor in a village, who may be only surviving on the NREGA promise of 100 days assured employment has to pay a 24 per cent rate of interest if he borrows money to buy a goat, and we in the cities can get interest-free loans or loans with a minimum rate of interest for buying a car.

As stated in (AZIZ, A., and B.D. PANDEY, B., D. 2017 p.19), from Islamic prospective the monetary economics and policy are governed by Islamic laws; to name a few of them Islam forbids accumulation of wealth, it protects the ownership of business i.e. if there are two partners the profit is shared on the basis of percentage which is initially agreed upon in the contract and loss is borne on the basis of the ratio of capital being invested by the two partners.

According to (AZIZ, A., and B.D. PANDEY, B., D. 2020. P, 10), the benefit of using Masjid for office space is many fold the cost is reduced and the Imam(the person who leads the prayer) and Muazin (Person who calls for prayer)of the Masjid can work in IMFI office and poor and poorest people of the locality can easily approach them. They can do survey of the locality and find out the exact financial situation of people in that particular locality.

(Mohammed, W.S., and Khalid Waheed, K. 2018. P. 63) IFMFIs do not charge 'interest' and principally operate by balancing financial goals and social objectives. Moreover, utilizing innovative products, these institutions share risk 
and benefits with the customers. In view of these holistic features, there is a hope that these institutions can become a boon for the poorest of the poor.

From Wikipedia, the free encyclopedia (29 November 2020) According to the 2011 Census of India, Hyderabad is the fourth-most populous city in India with a population of 6.9 million residents within the city limits, and has a population of 9.7 million residents in the metropolitan region, making it the sixth-most populous metropolitan area in India. As per the Census of India estimates, the urban poverty in Hyderabad is measured at $23 \%$ of total population.

Syed

Akbar

Available

at:

https://timesofindia.indiatimes.com/city/hyderabad/63-hyd-muslims-are-poor-survey/articleshow/75282242.cms

(Accessed: 30th November 2020). 63\% of Muslims in the city fall below the poverty line (BPL) and survive mostly on government doles, meagre daily earnings and charity.

\section{Research Methodology}

This is basically a qualitative research. However, to elucidate the qualitative data, quantitative data were also gathered on limited scale, Safa Baitul Maal is selected for the study, it is situated in Hyderabad India for the case study. The primary data required for the present study is collected using a 'Questionnaire' which was shared with the Present In charge (Respondent) Mufti Fayyaz of Safa Baitul Maal during the visit. The opinion of the borrowers regarding SBM operations was collected through an informal 'interview' which was conducted with the borrowers selected randomly. The authors also had informal interactions with the staff members to have a better idea of SBM operations. In addition, some of the information is also collected through telecom and Email. The secondary data related to the institution is collected from Annual Reports, websites, introductory materials, etc. Other required information has been collected from relevant books, journals, and online databases.

\subsection{About Safa Baitul Maal Educational Welfare and Charitable Trust}

Safa Baitul Maal Educational Welfare and Charitable Trust started in 2006 having its centre at Malakpet Hyderabad and the organization started microfinance started in 2014 after riots in Hyderabad city after general elections in the area of Kishan Bagh where poor Muslim vendors were looted by Sikhs for taking interest based loans for their small business and not able to return the money. The organization centre at Kishan Bagh headed by Mufti Fayyaz Sahab presently periodically and Abdul Kareem Faheem Sahab the representative of Kishan ganj area is monitoring the Islamic microfinance. The organization basically gives business loans to small vendors

Safa Baitul Maal (2018) Today, there are many people in our society who wish to do business but do not have the capital to start the same. With a small capital they can manage to earn a living for their family with their own experience. In this era, the small vendors who sell fruits and vegetables on pushcarts or in markets are so helpless that the money lenders and conventional microfinance take undue advantage of their poverty and lend them on interest basis, to be paid daily, they give principal in the morning and collect the principal and interest in the evening. The responsibility of saving these vendors from the curse of usury is on the wealthy individuals whose extra funds lie in banks for years. Doesn't their conscience compel them to help such distressed small vendors with interest free debt or provide monetary assistance for their business.

In order to save the small vendors of Kishan bagh from the curse of usury and to encourage them to do business, Safa Baitul Maal micro finance system. This effort began about six years ago with the intention of a view virtue seeking compassionate individuals and Alhamdullilah, today there is a formal mechanism. Interest free loans of Rs 5000 to Rs 10000 are given to small traders and a sum of Rs 300 is recovered each week and thus they pay back in about seventeen weeks and are refinanced until they develop their business. Hundreds of people of this area are utilizing this service. If the well off and affluent individuals of the society rise and participate in this campaign, it would become a source of livelihood for hundreds of poor vulnerable traders. Their prayers shall cause blessing in their wealth.

\subsection{Funding of Safa Baitul Maal Microfinance}

In 2014, few rich people gave to Safa Baitul Maal an amount of Rs 0.1 million, an amount of Rs 5000/- per person was given to small vendors who were devasted in riots after proper survey by SBM staff setting up their small business and repay period was seventeen weeks i.e. Rs 300/- per week. This fund in 2019 is increased 10 times and the organization have Rs 1 million/- denoted by many rich people as microfinance fund.

\subsection{Operational Procedure and Applicable Regulations}

The operational procedure and applicable regulation are simple and carried out by staff of SBM. The staff carries a survey of the houses of the loan applicants and verifies the information filled in the application checked. A 
background check is also carried out and guarantors of loan are contacted, after getting a positive report the application is approved by head of SBM centre and others in charge of microfinance. Initially Rs 5000/- or less is given as loan with a repay period of 17 weeks i.e. weekly repayment of repayment Rs 300/-. The money is again given as loan after 17 weeks after successful repayment if more money is required by customer with same repayment conditions. The individuals who are given a loan of Rs 10000/- are asked to repay Rs 600/- per week for seventeen weeks. If the instalment is missed then no penalty is charged from borrower as it is a type of interest and is prohibited in Islam.

\section{Result and Discussion}

SBM microfinance success can be evaluated from the fact that not a single penny is charged from the borrowers. The loan recovery rate is $100 \%$ in the last 6 years with exception of only one person who died after taking loan whose loan was waived of by unanimous decision of the organization. The outreach of the institution is slow but steady as the organization has neither government support nor extra fund to organize fund-raising events.

As stated by (Aziz, A., PANDEY, B. D., Shafique, S. (2017, p.311) The only way out for publicity is the word of mouth but is very effective.

Secondly, the laws are not favourable in India as stated by (Chakrabarty 2015, p.170) that financial regulatory authority of India has still not adopted Islamic micro-finance as an alternative way of financial inclusion while interest-free micro-finance is working in some parts of the country.

No collateral is required for issuing of loan, but only the approval of two members of masjid committee is required who sign on the Aadhar card and application form as the whole process is carried through Masjid situated in the locality. The nominal expenditure which is incurred in the process of microfinance is borne SBM charitable trust.

In 2019, loans of about Rs 1 Million were distributed on rotation basis and 1500 persons have benefited from i.e. 250 families have been saved from money lenders who are charging about $240 \%$ interest, these people give loan of Rs 5000/- ask for repayment of Rs 6000 in one month.

Seventeen weeks repayment time is given by SBM microfinance to borrowers with weekly payment of Rs 300/- for Rs 5000/- loan amount and Rs 600/- for Rs 10000/- loan amount. Due to stringent laws for registration of interest-free financial institution, organizations face serious hurdles in expansion of its services. The demand is really big and they have the "product" (service) in hand, but could not supply it due to legal restrictions.

\subsection{Growth of SBM Microfinance}

In year 2014, Rs 0.1 Million was made available by SBM microfinance through which 20 persons were given loans up to Rs 5000/-. Some microfinance customers pay Rs 100/- on daily basis and get loan again for their business. In, 2015, 70 persons were given loan. In 2016, loans of Rs 2093500/- (2.09million) were distributed on rotational basis to 355 small traders and their families were benefitted. In 2017, an additional amount of Rs 1,67312(Rs0.16Million) has been issued. In 2019, about 1500 persons have been benefitted from the interest free loans. The fund now has grown to Rs 1 million and loan amount of Rs 1 million is issued.

Some customers (borrowers) were interviewed like:- Mr Faizan took loan 2-3 times Rs 5000/- each and returned per week Rs 300/-, he runs a small shop. Mr Musa's son took loan on interest (from any other interest-based conventional microfinance institution )and had to pay Rs15000/- 20000/- as interest, now he has taken interest free loan from SBM of Rs 5000/- for setting a fruit hand cart and is relieved from paying interest, Mr Wahid took an interest free loan of Rs 3000/- for his tailoring shop. Many more persons were interviewed to get the insight of this activity from customers perspective, all gave a positive feedback.

According to (Mohammed, W.S. and Waheed, K. 2019, p 11) It is to be noted that there is a difference in the operational structure and policies between interest-free Islamic microfinance and interest-based conventional microfinance institutions. Hence, whether it is appropriate to have a direct comparative study of IFMFIs on conventional microfinance industry standards is a question that needs further discussion.

\section{Conclusion}

Safa Baitul Maal (SBM) microfinance has shown sustained growth though the organization is relatively new but it's rules which are Shariah compliant and interest free with no extra service or administrative charge whatsoever which is charged in most of the Islamic microfinance institutions to meet the overhead expenses. SBM uses the Masjid space for office due to which the expenses are reduced and rich people are requested to donate their recyclable waste like newspapers, used tyres etc. by selling these items money is arranged for the expenses. 
The outreach is limited to a locality of Kishan Bagh having a population of 70,000 people. One of the reasons for this is unfavourable Government policies for establishing, sustaining and expanding of Islamic microfinance institutions as stated by Chakrabarty, $A$. $K$. Second reason is that the people involved in the administrative activities take extra precaution as they have seen the disastrous failure of conventional microfinance at Hyderabad itself due to which many people committed suicide as stated by Aziz A. In the literature review the authors have quoted the words of President Obasanjo of Nigeria to point out the worst (ill) effects of interest-based finance and how it makes poor country and population poorer.

The mission of SBM microfinance unlike any conventional microfinance organization working elsewhere is not to make profits or increase the outreach but slow, steady, and sustainable growth of the poor making them self-sufficient and self-employed with moto that the return of their efforts will be given by Allah Subhan Wa Taa'la. In spite of the above reasons planning for opening the second branch of SBM microfinance is underway in the nearby locality within a short span of 6 years. If more people invest their time and money for development of this sector than fast and sustainable growth can be achieved.

The performance is excellent with $100 \%$ return of loans and full self-satisfaction that the organization is saving families and individuals from riba (interest) which is prohibited in Islam.

SBM Microfinance started with Rs 0.1 million as fund in 2014 and now the amount contributed by rich people as donation has reached to Rs 1 million to protect the poor. The success of an Islamic micro-finance institution can be regarded when poor are alleviated from poverty. The annual turnover is increased manifold since its inception when only 20 people were benefitted and 1500people were the beneficiaries in 2019 and now in 2020 the beneficiaries are 1800 , once an individual become a member he does not go out as he or she is protected from interest. Islamic (interest free) finance is instrumental in removing poverty one of the many aims of the institution. Complete lock down occurred due to Corona Virus pandemic, SBM personnel decided that 3 months extension to repayment time should be given to every borrower. No penalty is charged for any default of payment to the borrowers

\subsection{Scope of Future Work}

In the present study it is found that SBM mostly gives Qard-e-Hasana (interest free loans). If the scope of SBM is expanded to include other tools of business which are legal in Islamic economics for example micro credit like leasing and cost plus financing the amount used can be enhanced. Waqf cash can also be used in meeting the expenses of microfinancing donated by rich people.

The second suggestion to increase the outreach of Islamic Microfinance which is derived from the life of Prophet Mohammad (PBUH) is from his Madani part of life where he paired one rich helper(s) (Ansar) of Madinah to one migrant(s) of Mecca (Muhajir), in the present context if 1 million rich people are paired with 1 million poor (poorer and poorest) then it can be easy and effective solution for alleviation of poverty without any discrimination of religion or ethnic groups.

The third suggestion, if more people give their time and money Islamic microfinance institutions can be set up independently in each and every Masjid of India having outreach limited to locality nearby that Masjid then operations can be simplified, overhead expenses reduced and high performance can be achieved. This can also generate employment and improve standard of living.

It is recommended that further studies should be made to increase the outreach and growth with sustainability of the Islamic microfinance model being followed by SBM microfinance. Study, experimentation together with observations and corrective actions in operations are required.

\section{References}

Ahsanath., M. K., \& Rahmathullah, A. I. (2013). Interest free micro-finance institutions: a relief to rural society-a study based on Al-Ameen welfare society, Perimbalam (Malappuram District-Kerala). Researchjournali's Journal of Commerce, 1(1), 1-7.

Aslam, M. N. (2014). Role of Islamic microfinance in poverty alleviation in Pakistan: An empirical approach. International Journal of Academic Research in Accounting, Finance and Management Sciences, 4(4), 143-152. https://doi.org/10.6007/IJARAFMS/v4-i4/1288

Aziz, A., \& Pandey, B. D. (2017). Islamic Microfinance in Indian Perspective. Ansari Journal of Ultra Scientist of Engineering and Management, 1(1), 52-58. Retrieved 25 November 2019, from http://www.enggandmgtjournal.org/paper/12/ 
Aziz, A., \& Pandey, B. D. (2017). Study of Anjuman Anayat-E-Bewagan \& Yatama: A Prudential Institution Based in Bhopal India working on Islamic principles to alleviate poverty through Zakat. Ansari Journal of Ultra Scientist of Engineering and Management (AJUSEM), 3(2), 12-19. Retrieved 18 July 2020, from http://www.enggandmgtjournal.org/55/research-papers

Aziz, A., \& Pandey, B. D. (2020). Integrating Waqf with Islamic Microfinance Institutions: Growth Expansion and Sustainable Development in India- Short Communication. Ansari Journal of Ultra Scientist of Engineering and Management, 4(1), 9-11. Retrieved 25 July 2020, from http://www.enggandmgtjournal.org/paper/19/

Aziz, A., Pandey, B. D., \& Shafique, S. (2017). Sustainability and Growth of Islamic Micro-Finance: A Case Study of Anjuman Islahul Musclemen Based in Bhopal India. Journal of Modern Accounting and Auditing, 13(7), 306-312. https://doi.org/10.17265/1548-6583/2017.07.004

Chakrabarty, A. K. (2015). Islamic micro finance: Theoretical aspects and Indian status. The Journal of Commerce, 7(4), 169-182.

Ethica Institute of Islamic Finance. (2017). HANDBOOK OF ISLAMIC FINANCE. Retrieved 23 November 2019, from https://www.ethicainstitute.com/ebook.aspx

Mohammed, W. S., \& Khalid Waheed, K. (2018). Interest-free Microfinance in India: A Case Study of the Al-Khair Cooperative Credit Society. Journal of King Abdulaziz University, Islamic Economics, 31(1), 47-66. https://doi.org/10.4197/islec.31-1.3

Mohammed, W. S., \& Waheed, K. (2019). Interest-free microfinance in India: a case study of Bait-un-Nasr urban cooperative credit society. ISRA International Journal of Islamic Finance, 11(1). https://doi.org/10.1108/IJIF-10-2018-0114

$\begin{array}{llll}\text { Retrieved } & 30 & \text { November } & \text { 2020, }\end{array}$ https://timesofindia.indiatimes.com/city/hyderabad/63-hyd-muslims-are-poor-survey/articleshow/75282242.cms

Retrieved from http://timesofindia.indiatimes.com/articleshow/75282242.cms?utm_source=contentofinterest\&utm_medium=te xt\&utm_campaign=cppst

Safa Baitul Maal. (2018). Safa Baitul Maal. Hyderabad: Safa Baitul Maal Al Akram Graphic Solution Pvt Ltd.

Syed Akbar. Retrieved from http://timesofindia.indiatimes.com/articleshow/75282242.cms?utm_source=contentofinterest\&utm_medium=te xt\&utm_campaign=cppst

Wikipedia, the Free Encyclopedia. (2020, 29 November). Hyderabad. Retrieved April 22, 2020, from https://en.wikipedia.org/wiki/Hyderabad

\section{Copyrights}

Copyright for this article is retained by the author(s), with first publication rights granted to the journal.

This is an open-access article distributed under the terms and conditions of the Creative Commons Attribution license (http://creativecommons.org/licenses/by/4.0/). 